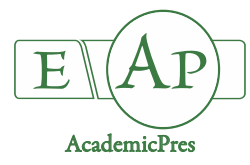

\title{
Use of Mycorrhiza to Reduce Mineral Fertilizers in Soilless Melon (Cucumis melo L.) Cultivation
}

\author{
Sultan DERE ${ }^{1,4}$, Ayse COBAN ${ }^{2,4}$, Yelderem AKHOUNDNEJAD ${ }^{3,4}$, \\ Suleyman OZSOY ${ }^{4}$, Hayriye Yildiz DASGAN ${ }^{4 *}$ \\ ${ }^{1}$ University of Siirt, Faculty of Agriculture, Department of Horticulture, Siirt, Turkey; sultan.dere@siirt.edu.tr \\ ${ }^{2}$ Ministry of Agriculture and Forestry, General Directorate of Agricultural Research and Policies (TAGEM), Ankara, \\ Turkey;cbnayse@gmail.com \\ ${ }^{3}$ University of Sirnak, Faculty of Agriculture, Department of Horticulture, Sirnak, Turkey; yakhoundnejad@sirnak.edu.tr \\ ${ }^{4}$ University of Cukurova, Faculty of Agriculture, Department of Horticulture, Adana, \\ Turkey;suleymanozsoy15@gmail.com;dasgan@cu.edu.tr (*correspondingauthor)
}

\begin{abstract}
Intensive use of mineral fertilizers in soilless growing systems can have adverse effects on the environment and human health and could be economically expensive. Aim of this study was whether it can be reduced mineral nutrients in soilless grown melon by using mycorrhizae inoculation. The experiment has been carried out in the early spring growing period in a greenhouse in the Mediterranean climate. The eight treatments have been applied: (1) 100\% Full nutrition (control), (2) $100 \%$ Full nutrition+mycorrhiza, (3) $80 \%$ nutrition, (4) $80 \%$ nutrition+mycorrhiza (5) $60 \%$ nutrition (6) $60 \%$ nutrition+mycorrhiza (7) $40 \%$ nutrition, (8) 40\% nutrition+mycorrhiza. Effects of mycorrhiza on melon plant growth, yield, fruit quality, and leaf nutrient concentrations were investigated. Arbuscular mycorrhizal fungi colonization is accompanied by plant growth increases in reduced nutrient levels. The mycorrhiza inoculation had a significant enhancing effect on total yield in soilless grown melon plants. The highest increasing effect on melon yield was observed in the " $80 \%$ nutrient+mycorrhiza", and AM- inoculated plants produced $49.5 \%$ higher melon yield $\left(12.4 \mathrm{~kg} \mathrm{~m}^{-2}\right)$ than that of control plants without mycorrhizae $\left(8.3 \mathrm{k} \mathrm{gm}^{-2}\right)$. AM-inoculation was also able to establish an improvement in Brix and EC of melon fruit. In the nutrient contents of leaves, there were slight increases in AM-inoculated plants, except P. The P content was significantly increased in AM-inoculated $80 \%$ nutrient plants as comparison to that of its control.
\end{abstract}

Keywords: Brix in melon; hydroponics; plant growth; saving-nutrients; yield

\section{Introduction}

Agricultural lands are decreasing due to erosion, desertification, urbanization and industrial establishments on agricultural land. In addition, the physical, chemical and biological properties of agricultural soils were significantly degraded due to intensive agricultural activities and monoculture plant cultivation (Gómez-López et al., 2004). New production methods have been searched in order to meet nutrient shortages of growing populations in the limited available agricultural land and to increase product quality and production efficiency. Soilless culture is one of the plant production techniques used in modern agriculture. Soilless culture or hydroponics allows to improve the control of growing medium and to avoid any possible problems for watering and maintaining of proper nutrient concentrations. A good environmental control of plant growth in soilless systems offers a proportionally higher yield and better quality crops compared to traditional soil cultivation (Dasgan et al., 2008). As the environmental conditions of the plants in the greenhouses approach, the plants' biological optimum levels, success in the cultivation increases. Control of the root zone conditions such as nutrients, $\mathrm{pH}, \mathrm{EC}$, water temperature, oxygen level, etc., can be achieved satisfactorily by soilless cultivation techniques (Guler et al., 1995; Dasgan et al., 2008). In soilless cultivation, mineral fertilizer usage is quite high. Intensive use of mineral fertilizers can have adverse effects on the environment and human health (high nitrate content etc.) and could be economically expensive.

Bio-fertilizers are defined as preparations containing living cells or latent cells of efficient strains of microorganisms that help crop plants uptake of nutrients by their interactions in the rhizosphere (Dobrojan et al., 2017). Recently, bio-fertilizers or microbial fertilizers which 
1332

contain fungus, bacteria, algae etc. became popular taking interest in soilless growing systems due to their environmentally approaches, efficiency on plant nutrition and decreasing cost of fertilization, inducing plant resistance to biotic and abiotic stress factors, and to increase plant growth and yield (Gul et al., 2008). Arbuscular mycorrhizal (AM) fungi are a large group of organisms and can be used as bio-fertilizers in agriculture.

Arbuscular mycorrhizal (AM) fungi occur in all soils, and commonly colonize in the roots of many plant species. The most common plant-microorganism relationship in nature is provided by mycorrhiza fungi. Mycorrhiza fungi can infect about $95 \%$ of the plants in the ecosystem. In plant-mycorrhiza collaboration; the plant provides carbon to the mycorrhizal fungus and the mycorrhizal fungus provides water and nutrients to the plant (Ortas et al., 2001). The best-known benefit of mycorrhiza infection is that it accelerates the growth of the plant. Other important benefits include improving soil structure, protecting plants from pathogens, increasing drought resistance, increasing plant survival, and impacting on beneficial plant hormones (Altuntas et al., 2015). Mycorrhizal fungi increase the plant root surface area with the production of large quantities of hyphae and can take the nutrients far from the root through the hyphae and transport them to the plant (George et al., 1992; Marschner, 1993). These fungi can increase plant growth and reproduction by enhancing the uptake of nutrients. AM fungi can also benefit plants by stimulating growth regulating substances, increasing photosynthesis, improving osmotic adjustment under drought and salinity stresses and increasing resistance to pest (Al-Karaki, 2006). Also, mycorrhizal inoculation reduces the quantity of fertilizer application, making it less than normally required for non-inoculated plant conditions (Charron et al., 2001). The AM fungi are absent in soilless growing systems. Uses of AM fungi on soilless grown pepper (Ikiz, 2003; Ikiz et al. 2009) and cucumber (Abak et al., 2008; Chen et al., 2017) plants in open substrate systems have been previously reported. In soilless grown tomato both open and closed (recycling) substrate systems (Dasgan et al., 2008) have been compared in the existence of mycorrhiza. Results indicated that mycorrhizal inoculation improved yield and fruit size, which can help alleviate the deleterious effects of re-cycling soilless systems for tomato crops. Abak et al. (2010) has reported better plant growing in soilless grown melon plants in a pot study with mycorrhiza. However, there is no previous study on the effects of mycorrhiza under reduced nutrients for soilless melon fruit production, yield and fruit quality. Therefore, fruit yield and some fruit quality parameters were discussed in this study. Melon production in the cool season in a greenhouse is mostly in high demand among growers due to having a good price. Recently, a soilless growing systems in melon greenhouses has become popular. However, intensive use of mineral fertilizers may not be adopted by some environmentally sustainable farmers and melon fruit consumers. In the present study, it is aimed to reduce the mineral fertilizers in soilless grown melon with bio-fertilizer mycorrhiza. The reduction of mineral fertilizers can provide benefits for the environment and human health. Reduction in the cost of mineral fertilizers could also be interesting for soilless melon growers.

\section{Materials and Methods}

Plant and mycorrhizal materials and experimental conditions

In the early spring season, the experiment was conducted in a research greenhouse at Cukurova University, Faculty of Agriculture, Department of Horticulture $\left(36^{\circ} 59^{\prime} \mathrm{N}, 35^{\circ} 18^{\prime} \mathrm{E}, 20 \mathrm{~m}\right.$ above sea level) in Adana/Turkey, by using cantaloupe melon (Cucumis melo) cv. 'Citirex $F_{1}$ '. The glass-covered greenhouse oriented in north-south direction was $12 \mathrm{~m} \times 42 \mathrm{~m}$ in size. A mixture of cocopeat and perlite (1:1) was used as a growing substrate. Mycorrhiza fertilizer under the trade name "Endo Roots Soluble" (ERS) was used in the experiment. There are nine different mycorrhiza species as cocktail preparation; Glomus intraradices, Glomus aggregatum, Glomus mosseage, Glomus clarum, Glomus monosporus, Glomus deserticola, Glomus brasilianum, Glomus etunicatum, Gigaspor margari. Melon plants were inoculated two times by the mycorrhizas, first in sowing by 600 spores and second in transplanting by 400 spores, therefore a total of 1000 mycorrhizal spores per plant were inoculated. Randomized complete block experimental design on 8 applications with 4 replicates, 16 plants in each replicate, were used. The seedlings were transplanted on 18 February to the soilless cultivation system. Plant density was 4.17 plants $\mathrm{m}^{-2}$. The mixture of cocopeat and perlite was filled containers made of white polycarbonate, in dimensions of $78 \times 38 \times 22 \mathrm{~cm}$. Each container contained 3 plants and 8 liters of the mixture substrate were used per plant.

\section{Nutrient solution and irrigation}

During the experiment, plants were irrigated by the open soilless system irrigation technique. The amount of nutrient solution applied in the treatments was determined based on a daily measured drainage fraction from the base of the growth containers. The range of drainage fraction measured was from 20 to $40 \%$ during the experimental period. Melon plants in " $100 \%$ nutrient" as control were supplied with the following nutrient solution modified from Guler et al. (1995) (in ppm): $\mathrm{NO}_{3}-\mathrm{N}$ (135-225), $\mathrm{NH}_{4}-\mathrm{N}$ (15-25), P (30-40), K (200-400), Ca (150-180), $\mathrm{Mg}$ (50-75), Fe (2.8-5.0), Mn (0.8-1.0), Cu (0.3-0.4), Zn (0.3-0.4), B (0.3-0.4) and Mo (0.05-0.1). Phosphorus concentration of the nutrient solution has been kept between 30 to $40 \mathrm{ppm}$ during the experiment. Reduced nutrient levels were obtained from the "100\% nutrient" solution. The $\mathrm{pH}$ and $\mathrm{EC}$ of the nutrient solution were maintained within a range of 6.0-6.5, EC 1.5-2.5 dS m $\mathrm{m}^{-1}$. The daily EC and $\mathrm{pH}$ values of supply and drain nutrient solutions were measured and controlled. The reduced nutrient levels with the mycorrhizal inoculation used in the experiment were as follows:

1) $100 \%$ Nutrition: Control treatment contained full strength nutrients,

2) $100 \%$ Nutrition with mycorrhizal inoculation,

3) $80 \%$ Nutrition: $20 \%$ reduced all nutrients,

4) $80 \%$ Nutrition with mycorrhizal inoculation,

5) $60 \%$ Nutrition: $40 \%$ reduced all nutrients,

6) $60 \%$ Nutrition with mycorrhizal inoculation,

7) $40 \%$ Nutrition: $60 \%$ reduced all nutrients,

8) $40 \%$ Nutrition with mycorrhizal inculcation. 


\section{Plant growth and fruit measurements}

Melon plants were compared on $55^{\text {th }}$ day after transplanting (DAT) for plant height, stem diameter between 3rd and 4th nods and leaf number. Total yield of melon (the period from June 01 to July 29) and some fruit quality parameters such as juice total soluble solid content (Brix), juice $\mathrm{pH}$ and $\mathrm{EC}$ were measured.

\section{Tissue elemental analysis}

In order to compare the nutritional status of the melon plants grown under different treatments, $49^{\text {th }}$ day after transplanting at early fruit set stage, leaf analysis for N, P, K, $\mathrm{Ca}, \mathrm{Mg}, \mathrm{Fe}, \mathrm{Mn}, \mathrm{Zn}$, and $\mathrm{Cu}$ were conducted. Samples of 8 leaves from each replication of all trails were collected. The leaf position on a plant was taken as a sample including the $5^{\text {th }}$ or $6^{\text {th }}$ leaves from the top. Melon leaves were dried at 65 ${ }^{\circ} \mathrm{C}$ for $48 \mathrm{~h}$. After drying, samples were grinded using a mill with a 20 mesh sieve. The leaf powder was turned to ash at $550{ }^{\circ} \mathrm{C}$ for about $6 \mathrm{~h}$ and the ash was dissolved in $3.3 \%$ $\mathrm{HCI}$. The concentrations of $\mathrm{K}, \mathrm{Ca}, \mathrm{Mg}, \mathrm{Fe}, \mathrm{Mn}, \mathrm{Zn}, \mathrm{Cu}$, $\mathrm{Na}$ in leaves were determined by atomic absorption spectrometry (Jones, 2001). Nitrogen and phosphorus in leaves were determined by Kjeldahl and Barton methods, respectively (Jones, 2001).

\section{Statistical analysis}

All data presented for different nutrient levels are averages of at least four repetitions of each treatment. Data were statistically analysed using one-way analysis of variance (ANOVA) and tested for significant $(\mathrm{P} \leq 0.05)$ treatment differences using Tukey's test.

\section{Results and Discussion} growth

The effects of arbuscular mycorrbizal (AM) fungi on plant

The growth parameters, such as plant height, stem diameter and the number of leaves were investigated in AMinoculated and non-inoculated plants grown reduced nutrient levels. A significant difference in plant growth was observed between AM-inoculated and non-inoculated plants (Table 1). The mycorrhiza had an increasing effect on plant height and AM-inoculated plants were taller than non-inoculated ones in reduced nutrient levels. Although the tallest plants were observed in " $80 \%$ nutrient+mycorriza" with $328.04 \mathrm{~cm}$, the mycorrhiza had the highest effect on plant height with a $14.5 \%$ increase in " $100 \%$ nutrient+mycorrhiza". Stem diameter of melon plants inoculated with-AM was increased with $4.9 \%, 4.7 \%$ and $2.8 \%$ as compared to that of their controls in $40 \%, 60 \%$, and $80 \%$ reduced nutrient levels, respectively (Table 1 ). Several reports in soilless grown tomato (Dasgan et al., 2008), melon (Abak et al., 2010) and pepper (Ikiz et al., 2009; Altuntas et al., 2015) were indicated significant improvements in plant height and stem diameter in AMinoculated plants as compared to that of controls. Mycorrhiza had an increasing effect on the number of melon leaves at reduced nutrient levels as a comparison to their controls (Table 1). The increasing ratio of number of leaves in AM-inoculated plants was between 7.3\% and $12 \%$. The highest increasing effect of $A M$ on the number of leaves was observed in the " $80 \%$ nutrient+mycorrhiza" application (12\%) (Table1). Plant growth results such as height, stem diameter and leaf number in soilless grown melon plants inoculated with AM were higher than those of control. AM fungi could benefit plants by stimulating growth regulating substances and increasing photosynthesis (Dasgan et al., 2008). AM colonization could promote the synthesis of chlorophyll, increase the root absorption area and root activity, promote the absorption and transport of water and nutrients, thereby enhancing the photosynthesis and plant growth in plants (Baslam et al., 2013; Chen et al., 2017). These results in soilless AM-inoculated melon were in agreement with previous studies in soil and soilless systems with different plant species, e.g. Cigsar et al. (2000) in cucumber, Charron et al. (2001) in onion, Sari et al. (2002) in garlic, Karagiannidis et al. (2002) in tomato, Ortas (2003) in maize, Ikiz (2003) and, Ikiz et al. (2009) in pepper, Dasgan et al. (2008) in tomato, Rehber (2004) and Abak et al. (2010) in melon, Westphal et al. (2008) in watermelon, and Dasgan et al. (2010) in squash.

The effects of arbuscular mycorrbizal (AM) fungi on
melon yield
An enhancement in total yield was observed in AMinoculated melon plants in reduced nutrient levels (Fig. 1). The highest and significant increasing effect of mycorrhiza on melon yield was observed in the " $80 \%$ nutrient+mycorrhiza" and AM inoculated plants produced $49.5 \%$ higher melon yield $\left(12.4 \mathrm{~kg} \mathrm{~m}^{-2}\right)$ than that of control plants without AM $\left(8.3 \mathrm{~kg} \mathrm{~m}^{-2}\right)$. The second highest yield was from the " $100 \%$ nutrient+mycorrhiza" by $16.4 \%$ yield increase as comparison to that of its control (Fig. 1). In the $60 \%$ and $40 \%$ nutrient levels, the yield-enhancing effect of mycorrhiza was relatively low, and yield increase ratios were $6.5 \%$ and $5 \%$, respectively.

Table 1. Effects of mycorrhiza on soilless melon plant growth parameters measured $55^{\text {th }}$ day after transplanting (DAT) in the reduced nutrient levels

\begin{tabular}{cccc}
\hline Application & $\begin{array}{c}\text { Plant height } \\
(\mathrm{cm})\end{array}$ & $\begin{array}{c}\text { Stem diameter } \\
(\mathrm{mm})\end{array}$ & Number of leaves per plant \\
\hline Nutrition $100 \%+\mathrm{M}$ & $317.33 \mathrm{ab}$ & $9.75 \mathrm{a}-\mathrm{c}$ & $24.6 \mathrm{c}$ \\
Nutrition $100 \%$ & $276.71 \mathrm{~cd}$ & $9.59 \mathrm{bc}$ & $24.5 \mathrm{c}$ \\
Nutrition $80 \%+\mathrm{M}$ & $328.04 \mathrm{a}$ & $10.34 \mathrm{ab}$ & $28.7 \mathrm{bc}$ \\
Nutrition $80 \%$ & $323.08 \mathrm{a}$ & $10.06 \mathrm{ab}$ & $25.6 \mathrm{bc}$ \\
Nutrition $60 \%+\mathrm{M}$ & $296.22 \mathrm{bc}$ & $10.37 \mathrm{a}$ & $27.2 \mathrm{ab}$ \\
Nutrition $60 \%$ & $299.04 \mathrm{~b}$ & $9.91 \mathrm{ab}$ & $25.3 \mathrm{bc}$ \\
Nutrition $40 \%+\mathrm{M}$ & $258.50 \mathrm{~d}$ & $9.03 \mathrm{~cd}$ & $22.2 \mathrm{~d}$ \\
Nutrition $40 \%$ & $268.46 \mathrm{~d}$ & $8.60 \mathrm{~d}$ & $19.9 \mathrm{e}$ \\
\hline
\end{tabular}




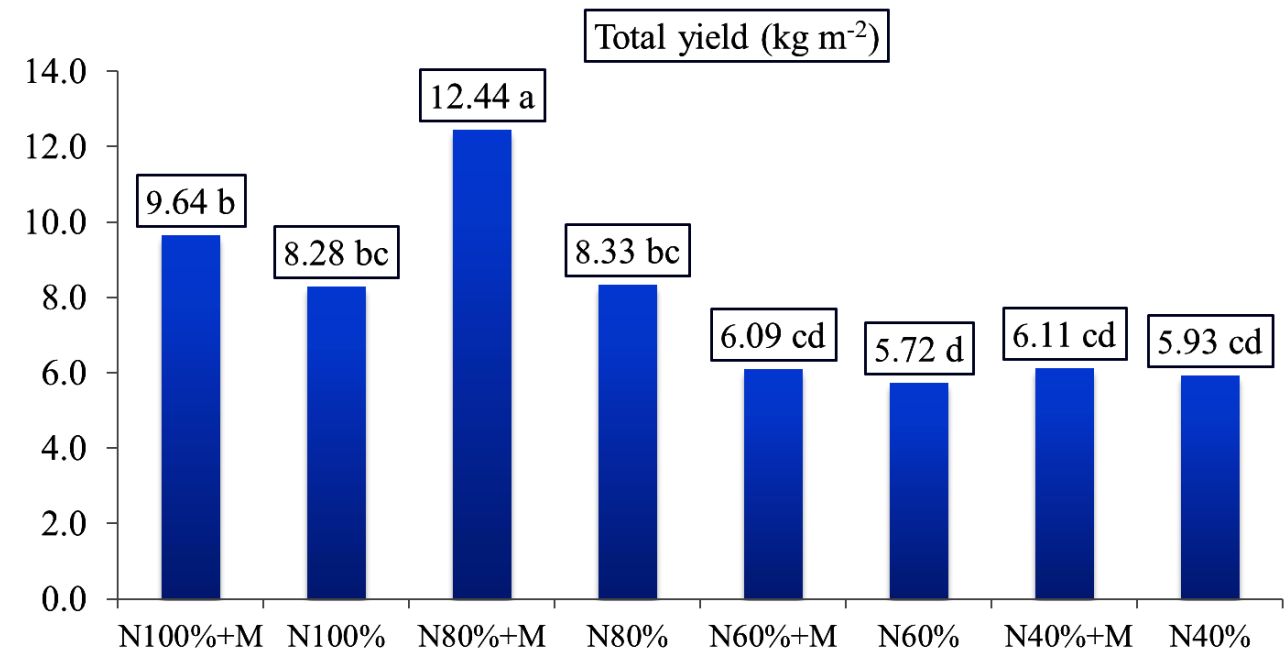

Fig. 1. Effect of mycorrhiza on soilless grown melon total yield in the reduced nutrient levels. N: Nutrition, M: Mycorrhiza. Different letters on a column indicate significant differences according to Tukey's test $(\mathrm{P} \leq 0.05)$

A better plant growth and biomass production, in AMinoculated plants, could promote photosynthesize more effectively and, therefore, could supply assimilates for fruit development and contribute to the higher total yield. This may be explained with effective photoassimilate's use of AM plants for fruit production (Dasgan et al., 2008). In AM conditions, since the root is colonized with mycorrhiza, there should be some benefits by an adequate supply of water and nutrients to the fruits. The fruits in AM plants may act as stronger sink organs for photoassimilates and can compete with other plant parts (Dasgan et al., 2008). Biomass accumulation is largely determined by the photosynthetic performance of a plant. AM inoculation enhanced both nutrient uptake and photosynthesis in plants (Chen et al., 2017). Michałojć et al. (2015) investigated the effect of AM-inoculation in two nutrient solutions; EC $2.6 \mathrm{mS} \cdot \mathrm{cm}^{-1}$ and $1.9 \mathrm{mS} \cdot \mathrm{cm}^{-1}$ in soilless grown tomato. They reported no effect of AM on the total and marketable yield; however fruits of tomato plants inoculated with AM contained significantly more sugars as compared to plants growing without mycorrhization. Maboko et al. (2013), reported tomato cultivation with mycorrhiza inoculation at reduced nutrient levels $(25 \%$ and $50 \%$ reduction) in heated and unheated tunnels. Reduced nutrient applications in heated tunnels, increased yield and product quality with mycorrhiza inoculation, however, there was no increased effect of AM in unheated tunnels. Dasgan et al. (2010) reported the results of soilless grown squash yield with AM-inoculation in $80 \%$ and $60 \%$ nutrient levels. The highest yield was $1019 \mathrm{~g} \mathrm{~m}^{-2}$ from " $80 \%$ nutrient+mychorriza". Westphal et al. (2008) reported that AM-inoculation in watermelon, and mycorrhiza increased only early yield and did not increase total yield. Dasgan et al. (2008) reported results of tomato yields in a closed and open soilless system with inoculation of mycorrhiza. The total highest yield with $19.5 \mathrm{~kg} \mathrm{~m}^{-2}$ was produced from an open system with mycorrhiza. The lowest yield was in the closed system without mycorrhiza as $16.8 \mathrm{~kg} \mathrm{~m}^{-2}$. Higher fruit production was found for the mycorrhizal versus the non-mycorrhizal plants in both closed and open systems.
The effects of arbuscular mycorrbizal (AM) fungi on melon fruit quality

EC values in melon fruit were higher in $\% 100$ and $\% 80$ nutrients with mycorrhizal inoculation as compared to their own controls. Melon fruit $\mathrm{pH}$ values were not statistically significant between applications (Table 2). Total soluble solids or Brix in fruit was increased by AM-inoculation. The increasing effect of mycorrhiza on Brix was highest in the " $100 \%$ nutrient+mycorrhiza", and a $33 \%$ Brix increase was recorded as a comparison to that of control. The Brix is the most important fruit parameter in the early season production of greenhouse melons. The sweeter melons are always more popular in the markets among the consumers. Increased photosynthesis may have contributed to increase Brix in fruit. The second and third Brix increases were $11.8 \%$ and $9.4 \%$ in the " $40 \%+$ mycorrhizal" and "60\%+mycorrhizal" applications as a comparison to their controls, respectively (Table 2). Michałojć et al. (2015) and Maboko et al. (2013) reported that AM inoculation increased tomato fruit quality especially Brix and dry matter. Dasgen et al. (2010) indicated that Brix in soilless grown squash fruits was increased by $13 \%$ in " $60 \%$ nutrient+mycorrhiza" application compared to $100 \%$ control nutrients without AM inoculation.

The effects of arbuscular mycorrbizal (AM) fungi on leaf nutrient concentrations

As the nutrient level decreased from $\% 100$ to $\% 40$, the nutrient concentrations in the leaf were decreased (Tables 3 and 4). In the results of leaf nutrient analysis, there were slight increases in AM-inoculated plants, except P. The P content was significantly increased in AM-inoculated $80 \%$ nutrient plants as a comparison to that of its control. The reason for slight nutrient increases in the leaf of AMinoculated plants as a comparison to control could be frequently irrigation scheduling with a nutrient solution in soilless systems, and optimal $\mathrm{pH}$ ranges in the nutrient solution. Plant nutrient requirements could be properly obtained by acidifying the nutrient solution in optimal $\mathrm{pH}$ ranges in soilless systems. Leaf analysis for $\mathrm{N}, \mathrm{P}, \mathrm{K}, \mathrm{Ca}, \mathrm{Mg}$, 
$\mathrm{Fe}, \mathrm{Mn}, \mathrm{Zn}$ and $\mathrm{Cu}$ showed that the nutrient concentrations recorded were within the range of sufficient levels (Hochmuth et al., 2012), except some levels in $40 \%$ nutrient levels. Many studies indicated that AM fungi contribute to plant growth via enhancement of mineral nutrient uptake (Dasgan et al., 2008; Maboko et al., 2013; Michałojć et al., 2015; Chen et al., 2017).

Table 2. The effect of mycorrhiza on soilless grown melon fruit quality in the reduced nutrient levels

\begin{tabular}{|c|c|c|c|}
\hline Application & $\mathrm{EC}\left(\mathrm{d} S \mathrm{~m}^{-1}\right)$ & $\mathrm{pH}^{*}$ & Brix (\%) \\
\hline Nutrition $100 \%+\mathrm{M}$ & $7.48 \mathrm{a}$ & 6.67 & $10.73 \mathrm{a}$ \\
\hline Nutrition $100 \%$ & $7.33 \mathrm{a}$ & 6.54 & $8.13 \mathrm{c}$ \\
\hline Nutrition $80 \%+\mathrm{M}$ & $7.12 \mathrm{a}$ & 6.56 & $8.80 \mathrm{bc}$ \\
\hline Nutrition $80 \%$ & $6.90 \mathrm{a}$ & 6.63 & $8.40 \mathrm{bc}$ \\
\hline Nutrition $60 \%+\mathrm{M}$ & $5.95 \mathrm{~b}$ & 6.82 & $8.68 \mathrm{bc}$ \\
\hline Nutrition $60 \%$ & $6.04 \mathrm{~b}$ & 6.72 & $7.95 \mathrm{c}$ \\
\hline Nutrition $40 \%+\mathrm{M}$ & $5.83 \mathrm{~b}$ & 6.50 & $9.88 \mathrm{ab}$ \\
\hline Nutrition $40 \%$ & $5.96 \mathrm{~b}$ & 6.83 & $8.85 \mathrm{bc}$ \\
\hline
\end{tabular}

M: Mycorrhiza; EC: electrical conductivity. *: non-significant difference. Different letters within a column indicate significant differences according to Tukey’s test (P $\leq$ $0.05)$

Table 3. Effects of mycorrhiza on soilless grown melon leaf macro-nutrient concentrations (dry matter basis) in the reduced nutrient levels

\begin{tabular}{|c|c|c|c|c|c|}
\hline Application & $\begin{array}{c}\mathrm{N} \\
(\%)\end{array}$ & $\begin{array}{c}\mathrm{P} \\
(\%)\end{array}$ & $\begin{array}{c}\mathrm{K} \\
(\%)\end{array}$ & $\begin{array}{l}\mathrm{Ca} \\
(\%)\end{array}$ & $\begin{array}{l}\mathrm{Mg} \\
(\%)\end{array}$ \\
\hline Nutrition $100 \%+\mathrm{M}$ & $6.28 \mathrm{a}$ & $0.51 \mathrm{a}$ & $3.91 \mathrm{a}$ & $1.90 \mathrm{ab}$ & $0.97 \mathrm{ab}$ \\
\hline Nutrition $100 \%$ & $6.01 \mathrm{ab}$ & $0.46 \mathrm{ab}$ & $3.26 \mathrm{ab}$ & $1.56 \mathrm{~b}$ & $0.97 \mathrm{ab}$ \\
\hline Nutrition $80 \%+M$ & $5.79 \mathrm{ab}$ & $0.51 \mathrm{a}$ & $3.55 \mathrm{ab}$ & $1.57 \mathrm{~b}$ & $0.87 \mathrm{~b}$ \\
\hline Nutrition 80\% & $5.99 \mathrm{ab}$ & $0.44 b c$ & $3.71 \mathrm{ab}$ & $1.81 \mathrm{ab}$ & $0.88 \mathrm{ab}$ \\
\hline Nutrition $60 \%+\mathrm{M}$ & $5.34 \mathrm{~cd}$ & $0.41 \mathrm{bc}$ & $3.12 \mathrm{ab}$ & $2.26 \mathrm{a}$ & $1.08 \mathrm{a}$ \\
\hline Nutrition 60\% & $5.10 \mathrm{~d}$ & $0.39 \mathrm{~cd}$ & $3.49 \mathrm{ab}$ & $2.01 \mathrm{ab}$ & $0.93 \mathrm{ab}$ \\
\hline Nutrition $40 \%+M$ & $4.65 \mathrm{e}$ & $0.39 \mathrm{~cd}$ & $2.05 \mathrm{c}$ & $1.65 \mathrm{~b}$ & $0.99 \mathrm{ab}$ \\
\hline Nutrition $40 \%$ & $4.59 \mathrm{e}$ & $0.35 \mathrm{~d}$ & $2.90 \mathrm{~b}$ & $2.25 \mathrm{a}$ & $0.96 \mathrm{ab}$ \\
\hline
\end{tabular}

M: Mycorrhiza. Different letters within a column indicate significant differences according to Tukey's test (P $\leq 0.05)$. Leaf samples collected during early fruit set stage $5^{\text {th }}$ or $6^{\text {th }}$ leaves from the top of the plant

Table 4. Effects of mycorrhiza on soilless grown melon leaf micro-nutrient concentrations (dry matter basis) in the reduced nutrient levels

\begin{tabular}{|c|c|c|c|c|}
\hline Application & $\mathrm{Cu}(\mathrm{ppm})$ & $\mathrm{Mn}(\mathrm{ppm})$ & $\mathrm{Fe}(\mathrm{ppm})$ & $\mathrm{Zn}(\mathrm{ppm})$ \\
\hline Nutrition $100 \%+\mathrm{M}$ & $16.90 \mathrm{a}$ & $170.62 \mathrm{ab}$ & $107.60 \mathrm{ab}$ & $62.97 \mathrm{a}$ \\
\hline Nutrition 100\% & $18.78 \mathrm{a}$ & $155.76 \mathrm{a}-\mathrm{c}$ & $109.43 \mathrm{a}$ & $57.38 \mathrm{ab}$ \\
\hline Nutrition $80 \%+\mathrm{M}$ & $12.75 \mathrm{bc}$ & $134.95 \mathrm{bc}$ & $94.11 \mathrm{ab}$ & $45.47 \mathrm{~b}$ \\
\hline Nutrition $80 \%$ & $13.46 \mathrm{~b}$ & $185.30 \mathrm{a}$ & $102.60 \mathrm{ab}$ & $57.35 \mathrm{ab}$ \\
\hline Nutrition $60 \%+\mathrm{M}$ & $13.09 \mathrm{bc}$ & $166.10 \mathrm{ab}$ & $98.26 \mathrm{ab}$ & $47.53 \mathrm{~b}$ \\
\hline Nutrition $60 \%$ & $11.83 \mathrm{bc}$ & $156.28 \mathrm{a}-\mathrm{c}$ & $100.64 \mathrm{ab}$ & $54.32 \mathrm{ab}$ \\
\hline Nutrition $40 \%+\mathrm{M}$ & $10.33 \mathrm{c}$ & $108.52 \mathrm{c}$ & $69.64 \mathrm{c}$ & $61.34 \mathrm{a}$ \\
\hline Nutrition $40 \%$ & $12.42 \mathrm{bc}$ & $131.93 \mathrm{bc}$ & $84.47 \mathrm{bc}$ & $54.27 \mathrm{ab}$ \\
\hline
\end{tabular}

M: Mycorrhiza. Different letters within a column indicate significant differences according to Tukey's test $(\mathrm{P} \leq 0.05)$. Leaf samples collected during early fruit set stage $5^{\text {th }}$ or $6^{\text {th }}$ leaves from the top of the plant

\section{Conclusions}

The present results showed that the AM-inoculation in reduced mineral nutrients could enhance plant growth, total fruit yield, and Brix of melon fruit. AM inoculation significantly increased the total melon yield in $80 \%$ nutrient level over that what can be achieved in $100 \%$ nutrient without mycorrhiza. AM-inoculation was also able to establish an improvement in Brix and EC of melon fruit. It was concluded that the AM inoculation could be used in soilless melon production in order to reduce mineral fertilization. It is believed that the use of mycorrhiza in soilless growing systems can be an environmentally sustainable approach for the enhancement of global food production in the future.

\section{Conflict of Interest}

The authors declare that there are no conflicts of interest related to this article.

\section{References}

AbakK, Dasgan HY, Rehber Y, Ortas I (2010). Effect of vesicular-arbuscular mycorrhizas on plant growth of soilless grown muskmelon. Acta Horticulturae 871:301-306.

Abak K, Rehber Y, Ylldzz M, Dasgan HY, Ortas I (2008). Toprakszz hryar yetiştiriciliğinde vesiküler arbisküler mikorizaların bitki gelişimi ve meyve verimine etkileri [Effects of vesicular arbuscular mychorrhizas on plant 
1336

growth and yield of soilless grown cucumber]. Turkey V National Horticulture Congress, September 2007, Erzurum-Turkey 2:258-261.

Al-Karaki GN (2006). Nursery inoculation of tomato with arbuscular mycorrhizal fungi and subsequent performance under irrigation with saline water. Scientia Horticulturae 109:1-7.

Altuntas O, Abak K, Dasgan HY (2015). Serada biber yetiştiriciliğinde arbusküler mikorizal fungus kullanımının bitki gelişimi ve verime etkileri [The Effects of using arbuscular mycorrhizal fungi on the plant development and yield in pepper growth in greenhouses]. Selcuk Tarim BilimleriDergisi 2(2):144-151.

Baslam M. Esteban R, Garcia-Plazaola JI, Goicoechea N (2013). Effectiveness of arbuscular mycorrhizal fungi (AMF) for inducing the accumulation of major carotenoids, chlorophylls and tocopherol in green and red leaf lettuces. Applied Microbiology and Biotechnology 97:3119-3128.

Charron G, Furlan V, Bernier-Cordou M, Doyon G (2001). Response of onion plants to arbuscular mycorrhizae. 1. Effects of inoculation method and phosphorus fertilization on biomass and bulb firmness. Mycorrhiza 11:187-197.

Chen S,Zhao H, Zou C, LiY, Chen Y, WangZ,... Ahammed GJ (2017). Combined inoculation with multiple arbuscular mycorrhizal fungi improves growth, nutrient uptake and photosynthesis in cucumber seedlings. Frontiers in Microbiology 8:2516.

Cigsar S, Sari N, Ortas I (2000). The effects of arbuscular mycorrhizal fungus on plant growth and yield of cucumber. Turkish Journal of Agriculture 24:571-578.

Dasgan HY, Aydoner G, Akyol M, (2010). Using of some microorganisms as bio-fertilizers in soilless grown squash for saving chemical nutrients. Acta Horticulturae 927:155-162.

Dasgan HY, Kusvuran S, Ortas I (2008). Responses of soilless grown tomato plants to arbuscular mycorrhizal fungal (Glomus fasciculatum) colonization in re-cycling and open systems. African Journal of Biotechnology 7(20):3606-3613.

Dobrojan S, Scedillãalaru V, Stratulat I, Dobrojan G (2017). Administration of algal bio-fertilizers to cultivation of tomatoes (Lycopersicum esculentum L.) under greenhouse conditions. Scientific Papers-Series A, Agronomy 60:73-76.

George E, Häussler K, Kothari SK, Li XI, Marschner H (1992).Contribution of mycorrhizal hyphae to nutrient and water uptake of plants. In: Mycorrhizas in ecosystems (Eds). Read DJ, Lewis DH, Fitter AH, Alexander IJ. CAB International Cambridge pp 4248.

Gómez-López, MD, Baille A, González-Real MM, Mercader-Hernández JM (2004). Growth and mineral nutrition of cucumber soilless culture. Acta Horticulturae 633:519-524.

Gul A, Kudoglu F, Tuzel Y, Tuzel H (2008). Effects of nutrition and Bacillus amyloliquefaciens on tomato (Solanum lycopersicum) growing in perlite. Spanish Journal of Agricultural Research 6(3):422-429.

Guler HY, Olympus C, Gerasopoulos D (1995). Effects of substrates on the quality characteristics of the hydroponically grown sweet melon (Cucumismelo).Acta Horticulturae 379:261-265.
Hochmuth G, Maynard D, Vavrina C, Hanlon E, Simonne E (2012). Plant tissue analysis and interpretation for vegetable crops in Florida. IFASExtension, University of Florida, https://edis.ifas.ufl.edu/ep081.

Ikiz O, Abak K, Dasgan HY, Ortas I (2009). Effect of mycorrhizal inoculation in soilless culture on pepper plant growth. Acta Horticulturae 807:533-539.

Ikiz O (2003). The effects of mycorrhiza on soilless pepper cultivation. Department of Horticulture, Institute of Natural and Applied Sciences, University of Cukurova, Adana-Turkey, $\mathrm{PhD}$ thesis, Code number 730.

Jones JB (2001). Laboratory guide for conducting soil tests and plant analysis. CRC Press pp 384 .

Karagiannidis N, Fotios B, Nikolaos S (2002). Effects of Verticillium wilt (Verticillium dabliae Kleb.) and mycorrhiza (Glomus mosseae) on root colonization, growth and nutrient uptake in tomato and eggplant seedlings. Scientia Horticulturae 94:145-156.

Maboko MM, Bertling I, Plooy CPD (2013). Arbuscular mycorrhiza has limited effects on yield and quality of tomatoes grown under soilless cultivation. Acta Agriculturae Scandinavica Section B-Soil and Plant Science 63(3):261-270.

Marschner H (1993). Zinc uptake from soils. In: Robson AD (Ed). Zinc in soils and plants. Developments in plant and soil sciences. Vol 55. Springer, Dordrecht.

Michałojć Z, Jarosz Z, Pitura K, Dzida K (2015). Effect of mycorrhizal colonization and nutrent solutions concentration on the yelding and chemical composition of tomato grown in rockwool and straw medium. Acta Scientiarum Polonorum Hortorum Cultus 14(6):1527.

Ortas I (2003). Effect of selected mycorrhizal inoculation on phosphorus sustainability in sterile and no-sterile soils in the Harran Plain in southern Anatolia.Journal of Plant Nutrition 26(1):1-17.

Ortas I, Kaya Z, Cakmak I (2001). Influence of VA-mycorrhiza inoculation on growth of maize and green pepper plants in phosphorus and zincdeficient soils. In: Horst WJ et al. (Eds). Plant Nutrition-Food Security and Sustainability of Agro-ecosystems, Kluwer Academic Publishers, Dordrecht pp 632-633.

RehberY(2004). The effectiveness of vesicular-arbuscular mycorrhizas in the soilless culture of muskmelon. Department of Horticulture, Institute of Natural and Applied Sciences, University of Cukurova, Adana-Turkey. MSc thesis, Code number 2365.

Sari N, Ortas I, Yetisir H (2002). Effect of mycorrhizal inoculation on plant growth, yield and phosphorus uptake in garlic under field conditions. Communications in Soil Sciences and Plant Analysis 33(13-14):21892201.

Westphal A, Snyder NL, Xing L (2008). Effects of moculations with mycorrhizal fungi of soilless potting mixes during transplant production on watermelon growth and early fruit yield. HortScience 43(2):354 360 . 